\title{
A Defect in the Regulation of Major Histocompatibility Complex Class II Gene Expression in Human HLA-DR Negative Lymphocytes from Patients with Combined Immunodeficiency Syndrome
}

\author{
Barbara Lisowska-Grospierre, Dominique J. Charron, Claude de Préval, Anne Durandy, \\ Claude Griscelli, and Bemard Mach \\ Unité d'Immunologie et Rhumatologie Pédiatriques, Institut National de la Santé et de la Recherche Medicale, U. 132, Hôpital \\ Necker-Enfants Malades, 149, rue de Sèvres, 75015 Paris, France; Laboratoire d'Immunogénétique, Centre-Hospitalo-Universitaire \\ Pitié-Salpétrière, 75013 Paris, France; and Département de Microbiologie, Université de Genève, 1205 Geneva, Switzerland
}

\begin{abstract}
Patients with an autosomal recessive combined immunodeficiency are characterized by an HLA negative phenotype of activated $\mathbf{T}$ and $B$ lymphocytes. To determine the molecular basis of this syndrome we have studied the biosynthesis of class I and II antigens and the expression of relevant genes in these patients.

The synthesis of the HLA $A, B$, and $C$ heavy chain is markedly decreased, while $\beta_{2}$ microglobulin is made in normal amounts. Biosynthesis of HLA-DR $\alpha$-chain and $\beta$-chain is abolished in the lymphocytes of these patients and there is a total absence of mRNA for either $\alpha$-chains or $\beta$-chains of HLA-DR. This indicates that the lack of class II antigen on these lymphocytes results from a block in the expression of HLA-DR genes. The Ii-chain, the invariant polypeptide associated intracellularly with HLA-DR, and its mRNA are made in normal amounts. Since the structural genes coding for class II polypeptides do not seem to be affected, the reported genetic defect in the patients concerns the regulation of the expression of HLA-DR genes.
\end{abstract}

\section{Introduction}

Major histocompatibility complex $(\mathrm{MHC})^{1}$ class II antigens are developmentally regulated, highly polymorphic cell surface glycoproteins that play a central role in the immune response $(1,2)$. HLA-negative B lymphocytes have been described in a group of patients with an autosomal recessive immunodeficiency. Defective expression of HLA antigens was first reported in patients lacking the class I antigens $(3,4)$, while in other

Received for publication 26 December 1984 and in revised form 10 April 1985.

1. Abbreviations used in this paper: $\mathrm{B}_{2} \mathrm{~m}$, anti- $\mathrm{B}_{2}$ microglobulin; $\mathrm{EBV}$, Epstein-Barr virus; IF, immunofluorescence; INF- $\gamma$, recombinant interferon gamma; MAb, monoclonal antibody; MHC, major histocompatibility complex; mRNA, messenger RNA; NP-40, Nonidet P40; PAGE, polyacrylamide gel electrophoresis; PBL, peripheral blood leukocytes; PHA, phytohemagglutinin; PWM, pokeweed mitogen.

J. Clin. Invest.

(c) The American Society for Clinical Investigation, Inc. 0021-9738/85/07/0381/05 \$1.00

Volume 76, July 1985, 381-385 patients, an absence of class II antigens was observed along with a reduced level of class $I$ antigens $(5,6)$. As expected from the crucial role of class II antigens in the immune response, these patients have a profound defect of antibody production and of cell-mediated immunity to thymo-dependent antigens.

We report here on the studies of class II deficient lymphocytes of patients with this type of combined immunodeficiency. The analysis concerns the biosynthesis of HLA antigens and demonstrates the absence of messenger RNA (mRNA) for the $\alpha$-chains and $\beta$-chains of HLA-DR in contrast to the presence of mRNA for the HLA-associated invariant chain. This defect in gene expression may represent a pathological counterpart of the HLA-DR negative lymphoblastoid cell line variants selected in vitro $(7,8)$.

\section{Methods}

Characterization of lymphocytes from immunodeficient patients. 12 patients with severe, repeated infections were shown to have an autosomal recessive combined immunodeficiency associated with an abnormal cell membrane expression of HLA antigens $(5,9)$. These patients differed from the 45 other patients with more common combined immunodeficiencies (10) investigated in our unit (adenosine desaminase deficiency, severe combined immunodeficiency with an increased amount of B cells or with a normal amount of $T$ and $B$ lymphocytes), whose lymphocytes showed a normal expression of HLA antigens. The twelve patients have normal level of circulating lymphocytes (9). The percentage of cells bearing HLA A, B, and C was always found to be decreased using immunofluorescence (IF) and complement fixation (5). Cytotoxicity and IF analysis of class II antigens failed to detect any positive cells on peripheral blood leukocytes despite a normal number of B lymphocytes in all except two children $(5,9)$. A search for immature T cells (OKT-6 positive) did not reveal any positive lymphocytes. Mitogen-induced proliferations were normal in all children as judged from $\left[{ }^{3} \mathrm{H}\right]$ thymidine incorporations, but there were no proliferations in response to antigens. In all instances, phytohemagglutinin (PHA)-induced blasts were HLA class II negative by IF with all monomorphic anti-DR antibodies used (9) and, in eight patients out of eight studied, by immunoprecipitation of biosynthetically labeled cell lysates. Four of those patients were selected for this study.

Antibodies. The MAb anti class I, clone W6/32 (Sera-Lab Ltd., Sussex, England) (11) and rabbit anti- $B_{2}$ microglobulin $\left(B_{2} \mathrm{~m}\right)$ (obtained from C. Vincent, Hopital Edouard Heriot, Lyon, France) were used to detect class I antigens. For class II, the monoclonal antibody (MAb) to native class II antigens were: MAb 2.06 (12), VI. 15c (13), 147 (14), 171 (15), MAb B8/12 (from A. F. Lemmonier, Centre D'Immunologie, Marseille, France), and LB 14/16 (obtained from J. Brochier, Hopital Edouard Heriot). In addition, two MAbs used, 147 and 171, were 
Table I. Membrane Expression of $T$ and $B$ Markers

\begin{tabular}{|c|c|c|c|c|}
\hline & $\mathrm{E}^{+}$ & OKT-3 & sIg & Fc $\gamma R$ \\
\hline Control (20) & $66.8 \pm 8.4$ & $77.5 \pm 9.1$ & $10.2 \pm 3.7$ & $9.2 \pm 6.8$ \\
\hline \multicolumn{5}{|l|}{ Patients } \\
\hline R.A. & 55 & 49 & $14-26$ & 13.0 \\
\hline O.A. & 55 & 64 & $13-16$ & 5.0 \\
\hline A.C. & $61-71$ & 83 & 2.5 & 4.1 \\
\hline N.H. & 75 & 75 & $12-22$ & ND \\
\hline
\end{tabular}

$\mathrm{E}^{+}$and $\mathrm{Fc} \gamma$ receptor $(\mathrm{FC} \gamma \mathrm{R})$ levels were assessed by rosetting in the presence of neuraminidase-treated sheep erythrocytes and of antibody-coated Ox erythrocytes respectively. OKT-3 and surface Ig (sIg) levels, by IF with MAb anti-T3 (Ortho Pharmaceutical Corp., Raritan, NJ) and rabbit F(ab)2' anti-human Fab of Ig (Nordic Immunological Laboratories, Tilburg, The Netherlands). Results are expressed as percentage of rosettes or of IF-positive lymphocytes. All patients have a normal number of lymphocytes. $\mathrm{E}^{+}$, lymphocytes bearing the receptors for sheep erythrocytes.

assayed in Western blot and found to react specifically with the $\alpha$ chains or the $\beta$-chains of HLA-DR class II antigen, respectively (15).

Cell labeling and immunoprecipitation. Patients and control peripheral blood leukocytes (PBL) were isolated by Ficoll-Hypaque gradient centrifugation and cultured in RPMI 1640 medium containing $10 \%$ human $\mathrm{AB}$ serum and $10 \mu \mathrm{g} / \mathrm{ml}$ of PHA. The nonadhering cells were collected at day 5 , the percentage of blasts was determined, and the cells were preincubated in methionine-free minimal essential medium for $60 \mathrm{~min}$. Then, $5 \times 10^{6}$ cells were incubated in $500 \mu \mathrm{l}$ of methionine-free minimal essential medium containing $100 \mu \mathrm{C} / \mathrm{ml}$ of $\left[{ }^{35} \mathrm{~S}\right]$ methionine (Amersham Corp., $500 \mathrm{Ci} / \mathrm{mmol}$ ) and $10 \%$ dialyzed fetal calf serum (FCS) at $37^{\circ} \mathrm{C}$ for $3 \mathrm{~h}$. Labeled cells were lysed in 50 $\mathrm{mM}$ Tris- $\mathrm{HCl}$ (pH 7.4), $150 \mathrm{mM} \mathrm{NaCl}, 2 \mathrm{mM}$ EDTA, 2 mM PMSF, and $1 \%$ Nonidet P40 (NP-40), for $30 \mathrm{~min}$ and centrifugated at 100,000 $g$ for $30 \mathrm{~min}$. Lysates from patients and control were adjusted to contain the same amounts of radioactivity and were immunoprecipitated with antibodies listed above, using formalin-fixed Staphylococcus aureus as immunoabsorbent. Washed precipitates were analyzed by sodium dodecyl sulfate polyacrylamide gel electrophoresis (SDS-PAGE) (12.5\%) (16). In the two-dimensional gel analysis, the first dimension was a nonequilibrium $\mathrm{pH}$ gradient electrophoresis, and the second was a $10 \%$ polyacrylamide slab gel (12). Gels were fluorographed, dried, and exposed to Kodak AR film (Eastman Kodak Co., Rochester, NY) for 5-20 d.

Induction of MHC class I and II antigens expression by recombinant $\gamma$-interferon. Patients and control PBL were incubated for $48 \mathrm{~h}$ in

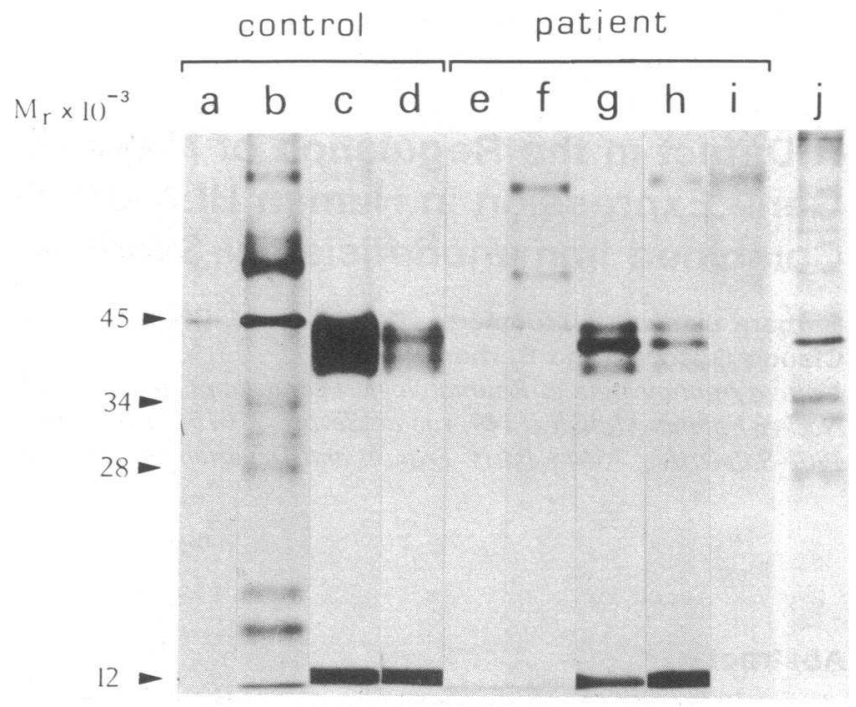

Figure 1. SDS-PAGE (5-20\%) analysis of immunoprecipitates of cell lysates of $\left[{ }^{35}\right.$ S $]$ methionine-labeled blasts from patient A.C. and control. Patient and control PHA or PWM blasts were at day 5 continuously labeled with $\left[{ }^{35}\right.$ S $]$ methionine, extracted with NP-40, and immunoprecipitated. Lanes precipitates from control lysate; lanes $e-h$, from patient A.C. PHA-blasts; lane $i$, from patient's PWM-blasts. The antibodies used sequentially were: $a$ and $e, 4 \mu \mathrm{l}$ of NMS; $b, f$, and $i, 20 \mu \mathrm{l}$ of MAb anti-class II 2.06; $c$ and $g, 3 \mu \mathrm{l}$ of MAb anticlass I, W6/32; $d$ and $h, 3 \mu$ of rabbit anti-B $\mathbf{B}_{2}$ microglobulin. Lane $j$ shows the anti-class II precipitate (MAb B8/12) obtained from the EBV-transformed patients' cells labeled with $\left.{ }^{35} \mathrm{~S}\right]$ methionine $5 \mathrm{wk}$ after transformation. The positions of relative molecular weight $\left(M_{\mathrm{r}}\right)$ markers are shown to the left.

RPMI 1640 containing $10 \%$ fetal calf serum in the absence or presence of $500 \mathrm{IU} / \mathrm{ml}$ of a preparation of purified recombinant interferon gamma (INF- $\gamma$ ) (17) obtained through the courtesy of Dr. W. Fiers, Rijksun University, Gent, Belgium. At the end of this incubation cells were labeled, as described above, with $200 \mu \mathrm{C} / \mathrm{ml}$ of $\left[{ }^{35} \mathrm{~S}\right]$ methionine for $2 \mathrm{~h}$. Lysates were proceeded and precipitated, as described above.

RNA preparation and analysis. RNA preparation and Northern blot analysis were performed as already reported (18). In brief, total RNA was prepared according to Chirgwin et al. (19), denatured in glyoxal (20), electrophoresed in a 1.8\% agarose gel, transferred to diazobenzyloxymethyl paper, and hybridized with nick-translated ${ }^{32} \mathrm{P}$ cDNA probes. After hybridization with $\alpha$-DR (21), $\beta$-DR (22), and Iichain (23) cDNA probes under high stringency conditions, the filter

Table II. Membrane Expression of Class I and II Antigens on Resting and Culture Lymphocytes*

\begin{tabular}{|c|c|c|c|c|c|}
\hline & \multicolumn{3}{|c|}{ Resting lymphocytes } & & \\
\hline & \multirow[b]{2}{*}{ Class I } & \multicolumn{2}{|l|}{ Class II } & \multicolumn{2}{|c|}{ PHA-induced blasts } \\
\hline & & Untreated & ${ }^{+}$INF- $\gamma \neq$ & Class I & Class II \\
\hline Controls (10) & 100 & $0.5 \pm 6.5$ & $11.2 \pm 7.1$ & 100 & $23.4 \pm 9.8$ \\
\hline \multicolumn{6}{|l|}{ Patients } \\
\hline R.A. & 7 & $<1$ & $\leqslant 1$ & 37 & 0 \\
\hline O.A. & 53 & 0 & ND & 23 & 0 \\
\hline A.C. & 40 & $<1$ & 1 & 20 & 0 \\
\hline N.H. & 67 & $<1$ & $\leqslant 1$ & 76 & 0 \\
\hline
\end{tabular}

* Detected by IF with, respectively, MAb anti-class I, W6/32 (Sera-Lab Ltd.), and MAb anti-class II (Ortho-Pharmaceutical Corp.). Results are expressed as the percentage of immunofluorescent lymphocytes. $\ddagger$ Incubated for $24 \mathrm{~h}$ with $800 \mathrm{IU} / \mathrm{ml}$ of INF- $\gamma$, which provoked an increase of class II expression on U.937 line from 2 to $64 \%$. 

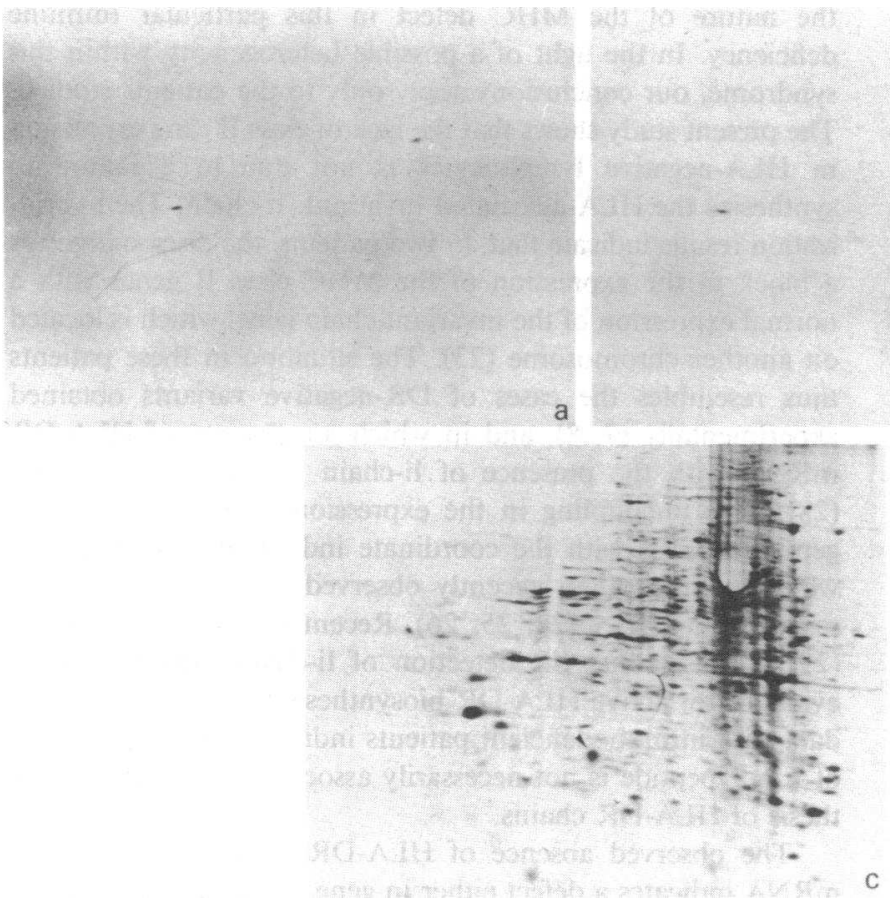

Figure 2. Two-dimensional gel analysis of immunoprecipitates or total lysates of $\left[{ }^{35}\right.$ S]methionine-labeled PHA blasts of patient A.C. The first dimension is a nonequilibrium $\mathrm{pH}$ gradient electrophoresis, according to O'Farrel (17). The second is a $10 \%$ polyacrylamide slab gel. $5 \mu \mathrm{l}$ of MAb $147(a)$ or of MAb $171(b)$, which recognize, respectively, free $\alpha$-chains and $\beta$ chains as well as $\alpha-\beta$ complex, were used to obtain immunoprecipitates of $\left[{ }^{35}\right.$ S]methionine-labeled cell lysate from blasts from patient A.C. For total cell lysate $(c), 5 \mu \mathrm{l}$ of labeled cell extract was diluted with $45 \mu$ l (1:10 ratio) of isoelectrofocusing sample buffer. Similar results were obtained with cells of three other patients. was washed (final washes, $0.1 \times \mathrm{SSC}$ at $68^{\circ} \mathrm{C}$ ) and submitted to autoradiography. Dehybridization of the filter was performed in $99 \%$ formamide, $10 \mathrm{mM}$ phosphate buffer, $\mathrm{pH} 7.5,5 \mathrm{mM}$ at $68^{\circ} \mathrm{C}$.

\section{Results}

The four patients described had a normal or subnormal amount of $T$ and $B$ lymphocytes (Table I) and exhibited normal proliferative responses to mitogens. The abnormal HLA class I and II phenotype of their lymphocytes and of PHA and pokeweed mitogen (PWM)-induced blasts (Table II) prompted further investigations.

In all patients, the biosynthesis of HLA antigens was abnormal in several labeling experiments for each patient. The heavy chain of class I antigen was decreased as compared with controls (Fig. 1, $c$ and $g$ ), contrasting with a normal synthesis of $\beta_{2}$ microglobulin (Fig. $1, d$ and $h$ ). With a series of different monoclonal antibodies specific for MHC class II antigens, we repeatedly failed to detect any class II molecules in the lysates of the PHA-induced blasts (Fig. $1, b$ and $f$ ) or of PWMstimulated blasts (Fig. 1, $i$ ). Furthermore, even the reagents specific for the nonassembled $\alpha$-chains and $\beta$-chains of HLADR could not detect either $\alpha$ or $\beta$ polypeptides (Fig. 2, $a$ and $b$ ). In contrast, the invariant Ii-chain was readily detected in cells of all four patients when the total lysates were analysed by two-dimensional gel electrophoresis (Fig. 2,c).

Since INF- $\gamma$ is known to induce the expression of class II antigens in vitro $(24,25,26)$, we tested its effect on the patients' leukocytes. While the preincubation of the PBL in

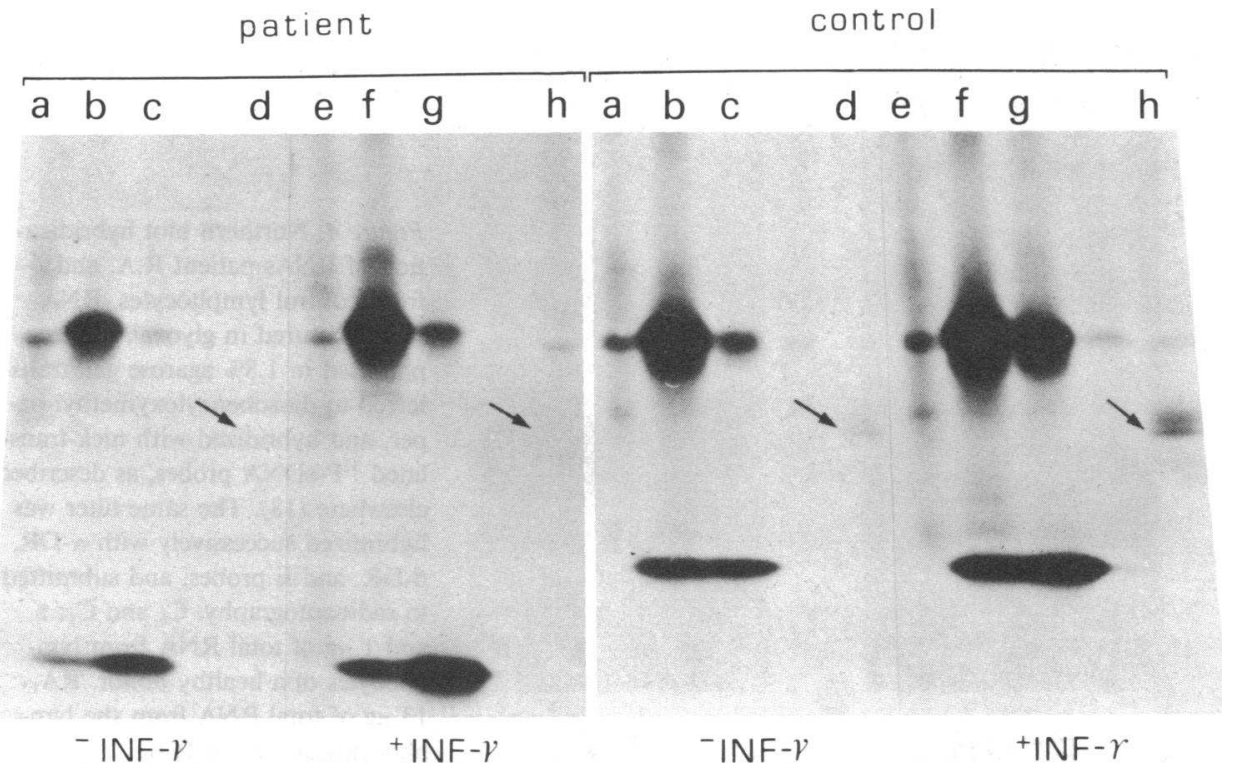

Figure 3. Immunoprecipitates of $\left[{ }^{35}\right.$ S]methionine labeled cell lysates from patient and control PBL incubated in vitro with INF $\gamma$. At the end of $48 \mathrm{~h}$ of in vitro culture in absence (-INF) or presence $\left({ }^{+}\right.$INF) of $\gamma$-interferon, cells were labeled with $\left[{ }^{35}\right.$ S]methionine, extracted with NP-40, and immunoprecipitated. Doses of MAbs used to precipitate class I and II antigens were the same as in Fig. 1. Sequence of antibody additions was: $a$ and $e$, NMS; $b$ and $f$ MAb W6/32; $c$ and $g, \mathrm{Rb}$ anti-B $\mathrm{B}_{2} \mathrm{~m} ; d$ and $h$, MAb 2.06 . Lanes $a-e$, precipitates from noninduced cells; lanes $f-j$, from induced cells. 
the presence of INF- $\gamma$ clearly augmented the biosynthesis of class I antigen (Fig. 3, left, $b, c$, and $f, g$ ), it did not allow detection of class II antigen (Fig. 3 , left, $h$; and Table II). A clear increase of class II molecules was observed in control cells after an incubation with INF- $\gamma$ (Fig. 3, right, $d$ and $h$, arrows).

Thus, neither mitogens nor the INF- $\gamma$ could induce expression of class II antigens in the leukocytes of these patients. Yet, these cells can respond to INF- $\gamma$ as shown by the increase in class I expression. In addition, a B cell line was established with Epstein-Barr virus (EBV) from DR-negative cells from one patient. After several weeks of culture, however, it reverted to a class II positive phenotype (Fig. $1, j$ ).

In view of these findings, it was of interest to explore directly the level of activity of the HLA-DR genes of these lymphocytes and to establish if the defect was due to a block in gene expression. RNA was prepared from PHA-induced blasts of two patients. These RNAs were analysed by Northern blot hybridization for the presence of mRNA specific of HLADR, $\beta$-chains, or Ii-chains, using our specific cDNA probes $(21,22,23)$. The same blot containing 6 and $1 \mu \mathrm{g}$ of control RNA and $13 \mu \mathrm{g}$ of RNA from lymphocytes of patient R.A. was hybridized successively with $\alpha$-DR, $\beta$-DR, and Ii probes (Fig. 4). In the patient cells, no mRNA for HLA-DR $\alpha$ or $\beta$ chain can be detected, whereas the mRNA for the li chain was present in an amount comparable to control. Similar results were obtained for RNA of patient A.C. (data not shown). Even after a prolonged exposure of the same filters, no class II mRNA could be detected in the lanes corresponding to the patients' RNA.

\section{Discussion}

Because the expression of MHC class I and II antigens is regulated in different cell populations and is clearly essential in intercellular events leading to an immune response $(1,2)$ such as antigen presentation (27), it was important to identify the nature of the MHC defect in this particular immune deficiency. In the light of a possible heterogeneity within this syndrome, our conclusions apply only to the patients studied. The present study shows that the lack of class II gene expression in HLA-negative lymphocytes is not due to a failure to synthesize the HLA-associated invariant, Ii-chain. The hybridization results indicate that, in two patients, the disease involves a block in the expression of the MHC class II genes with a normal expression of the invariant chain gene, which is located on another chromosome (23). The situation in these patients thus resembles the cases of DR-negative variants obtained experimentally $(7,8)$, and in which an absence of HLA-DR mRNA with the presence of Ii-chain mRNA was observed (28). This uncoupling in the expression of HLA-DR and Ii genes contrasts with the coordinate induction of both genes, which we and others recently observed at the RNA level in response to INF- $\gamma(24,25,26)$. Recently, Volc-Platzer et al. (29) proposed that the detection of Ii-chain provides strong evidence for active HLA-DR biosynthesis by a given cell. Our data with immunodeficient patients indicate that the synthesis of Ii polypeptide is not necessarily associated with the biosynthesis of HLA-DR chains.

The observed absence of HLA-DR $\alpha$-chain and $\beta$-chain mRNA indicates a defect either in gene transcription or in the processing of these transcripts, rather than a block of mRNA translation or deficient polypeptide assembly, as it is observed in the case of Daudi cells for HLA class I and $\beta_{2}$ microglobulin (18). A massive deletion of HLA-DR genes could be ruled out in this syndrome by DNA/DNA hybridization studies (Marcadet, A., D. Cohen, J. Dausset, A. Fischer, A. Durandy, and C. Griscelli, submitted for publication). In addition, reversion to DR positive B lymphoblasts was observed in the EBVinduced culture of lymphocytes from one patient. Thus, the apparent integrity of the structural genes for HLA-DR indicates that the genetic defect in the patients studied is in the regulation of the expression of DR genes. Furthermore, two siblings with this immunodeficiency were shown to have
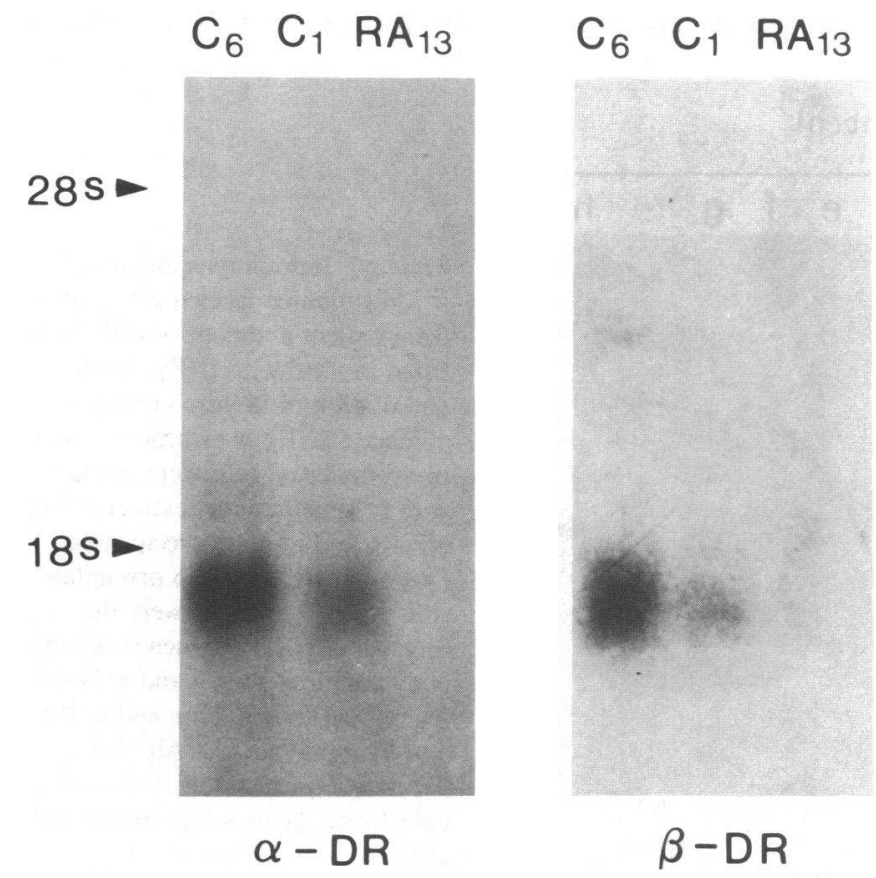

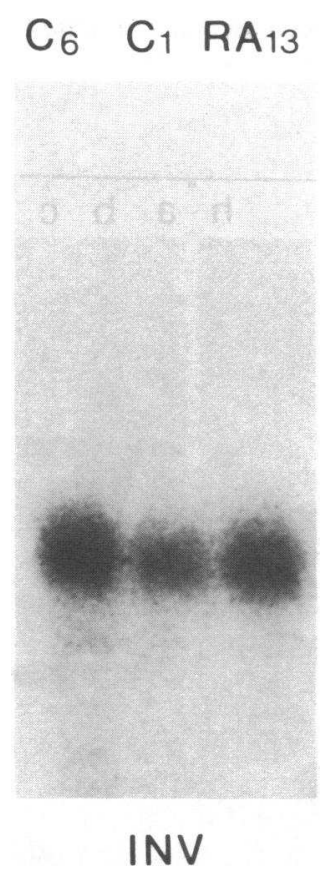

Figure 4. Northern blot hybridization of RNAs patient R.A. and from control lymphocytes. RNA was denatured in glyoxal, electrophoresed in $1.8 \%$ agarose gel, transferred to diazobenzyloxymethyl-paper, and hybridized with nick-translated ${ }^{32} \mathrm{P}$-cDNA probes, as described elsewhere (18). The same filter was hybridized successively with $\alpha$-DR, $\beta$-DR, and li probes, and submitted to radioautography. $C_{6}$ and $C_{1}: 6$ and $1 \mu \mathrm{g}$ of total RNA from lymphocytes of a healthy donor. $\mathrm{RA}_{13}$ : $13 \mu \mathrm{g}$ of total RNA from the lymphocytes of patient R.A. 
different HLA haplotypes. In conclusion, our data strongly suggest the existence of a transactive pleiotrophic $\mathrm{MHC}$ regulatory gene, possibly located outside of the MHC.

\section{Acknowledgments}

The skillful assistance of Mrs. M. A. Doyenette and of P. Turmel is gratefully acknowledged. We thank Dr. J. Brochier and A. F. Lemmonier for monoclonal antibodies anti class II, and Dr. C. Vincent for rabbit anti- $\mathrm{B}_{2}$ microglobulin serum.

This work was supported by grants from Institut National de la Santé et de la Recherche Medicale and from the Swiss National Fund for Scientific Research.

\section{References}

1. McDevitt, H. O. 1976. Functional analysis of Ia antigens in relation to genetic control of the immune response. In The Role of the Products of the Histocompatibility Gene Complex in Immune Responses. D. H. Katz and B. Benaceraff, editors. Academic Press, Inc., New York. 257.

2. Benaceraff, B. 1981. In The Role of the Major Histocompatibility Complex in Immunobiology. M. E. Dorf, editor. Garland Publishing, Inc., New York. 255.

3. Touraine, J. L., H. Betuel, G. Suillet, and M. J. Jeune. 1978. Combined immunodeficiency disease associated with absence of cell surface HLA A and B antigens. J. Pediatr. 93:47-50.

4. Schuurman, R. K. B., J. J. Van Rood, J. M. Vossen, P. A. Schellekens, T. M. Felkampvroom, E. Doyer, F. Gmelig-Meyling, and H. K. A. Visser. 1979. Failure of lymphocyte membrane expression in two siblings with combined immunodeficiency. Clin. Immunol. Immunopathol. 14:18-23.

5. Griscelli, C., A. Durandy, J. L. Virelizier, J. Hors, V. Lepage, and J. Colombani. 1980. Impaired cell to cell interactions in partial immunodeficiency with variable expression of HLA antigens. In Primary Immunodeficiencies. M. Seligman and H. Hitzig, editors. Elsevier/ North Holland, Amsterdam. 499.

6. Durandy, A., J. L. Virelizier, and C. Griscelli. 1983. Enhancement by interferon of membrane HLA antigens in patients with combined immunodeficiency with defective HLA expression. Clin. Exp. Immunol. 52:173-178.

7. Gladstone, P., and D. Plous. 1978. Stable variants affecting B cell alloantigens in human lymphoid cells. Nature (Lond.). 271:459461.

8. Accolla, R. S. 1983. Human B cell variants immunoselected against a single Ia subset have lost expression of several Ia antigens subsets. J. Exp. Med. 157:1053-1058.

9. Griscelli, C., A. Fischer, B. Lisowska-Grospierre, et al. 1984. Clinical and immunological aspects of combined immunodeficiency with defective expression of HLA antigens. In Progress in Immunodeficiency Research and Therapy. C. Griscelli and J. Vossen, editors. Excerpta Medica, Amsterdam. p. 19.

10. Report of the World Health Organization scientific group. 1983. Immunodeficiencies. Clin. Immunol. Immunopathol. 28:450.

11. Barnstable, C. J., W. F. Bodmer, G. Brown, G. Galfre, C. Milstein, A. F. Williams, and A. Ziegler. 1978. Production of monoclonal antibodies to group A erythrocytes, HLA and other human cell surface antigens: new tools for genetic analysis. Cell. 14:9-17.

12. Charron, D. J., and H. O. McDevitt. 1980. Characterization of HLA-DR region antigens by two-dimensional gel electrophoresis. J. Exp. Med. 152:18s-36s.
13. Guy, K., V. Van Heyningen, B. B. Deane, and C. M. Steal. 1982. Differential expression and serologically distinct subpopulations of human Ia antigens detected with monoclonal antibodies to Ia $\alpha$ and $\beta$ chains. Eur. J. Immunol. 12:942-956.

14. Goyert, S. M., and J. Silver. 1981. Isolation of I-A subregionlike molecules from subhuman primates and man. Nature (Lond.). 294:266-269.

15. Charron, D. J., V. Lotteau, and P. Turmel. 1984. Hybrid HLADC antigens: molecular evidence for the gene trans-complementation. Nature (Lond.). 312:157-160.

16. Laemmli, U. K. 1970. Cleavage of structural proteins during the assembly of head of bacteriophage 4. Nature (Lond.). 227:680685 .

17. Devos, R., C. Opsomer, S. J. Scahill, J. van der Heyden, and W. Fiers. 1984. Purification of recombinant glycosylated human gamma interferon expressed in transformed Chinese hamster ovary cells. J. Interferon Res. 4:461-470.

18. De Préval, C., and B. Mach. 1983. The absence of $\beta_{2}$ microglobulin in Daudi cells: active gene but inactive messenger RNA. Immunogenetics. 17:133-140.

19. Chirgwin, J. M., A. E. Przybyla, R. J. McDonald, and W. J. Rutter. 1979. Isolation of biologically active ribonucleic acid from sources enriched in ribonuclease. Biochemistry. 18:5294-5302.

20. McMaster, G. K., and G. G. Caramichael. 1977. Analysis of single and double-stranded nucleic acid on polyacrylamide and agarose gels by using glyoxal and acridine orange. Proc. Natl. Acad. Sci. USA. 74:4835-4839.

21. Wake, C. T., E. O. Long, M. Strubin, N. Gross, R. S. Accolla, and B. Mach. 1982. Isolation of cDNA clones encoding HLA-DR $\alpha$ chains. Proc. Natl. Acad. Sci. USA. 79:6979-6983.

22. Long, E. O., C. T. Wake, M. Strubin, N. Gross, R. S. Accolla, S. Carrel, and B. Mach. Isolation of distinct cDNA clones encoding HLA-DR $\beta$ chains by use of an expression assay. Proc. Natl. Acad. Sci. USA. 79:7465-7469.

23. Long, E. O., M. Strubin, C. T. Wake, N. Gross, S. Carrel, P. Goodfellow, R. S. Accolla, and B. Mach. 1983. Isolation of cDNA clones for the p33 invariant chain associated with HLA-DR antigens. Proc. Natl. Acad. Sci. USA. 80:5714-5718.

24. Mach, B., C. de Préval, and J. Gorski. 1984. Molecular genetics of class II genes and the regulation of their expression. In Progress in Immunodeficiency Research and Therapy. C. Griscelli and J. Vossen, editors. Excerpta Medica, Amsterdam. 11.

25. Collins, T., A. J. Korman, C. T. Wake, J. M. Boss, D. J. Kappes, W. Fiers, K. A. Ault, M. A. Gimbrone, Jr., J. L. Strominger, and J. S. Pober. 1984. Immune interferon activates multiple class II MHC genes and the associated invariant chain gene in human endothelial cells and dermal fibroblasts. Proc. Natl. Acad. Sci. USA. 81: 4917-4921.

26. Virelizier, J. L., N. Perez, F. Arenzana-Seisdedos, and R. Devos. 1984. Pure interferon gamma enhances class II HLA antigens on human monocyte cell lines. Eur. J. Immunol. 14:106-111.

27. Matis, L. A., P. P. Jones, D. B. Murphy, S. M. Hedrick, E. A. Lerner, C. A. Janeway, J. McNicholson, and R. M. Schwartz. 1982. Immune response gene function correlates with the expression of an Ia antigen. J. Exp. Med. 155:500-515.

28. Long, E. O., B. Mach, and R. S. Accolla. 1984. Ia-negative Bcell variants reveal a coordinate regulation in the transcription of the HLA class II gene family. Immunogenetics. 19:349-356.

29. Volc-Platzer, B., O. Majdic, W. Knapp, K. Wolff, W. Hinterberger, K. Lechner, and G. Stingl. 1984. Evidence of HLA-DR antigen biosynthesis by human keratinocytes in disease. J. Exp. Med. 159: 1784-1789. 